\title{
Human rights and armed conflicts \\ On the 500th anniversary of the birth of Las Casas (1474-1874-1974)
}

by Paul de Geouffre de La Pradelle

The author of the article printed below is Vice-President of the Institute of International Law and had attended the 1949 Diplomatic Conference in Geneva as a delegate. In October 1974 he organized at the Institut d'Etudes politiques d'Aix-en-Provence a colloquium on Las Casas and Human Rights. The article is reproduced, with the author's permission, from a paper presented at the colloquium.

\section{Introduction}

With the theological jurists of the Middle Ages, universally recognized as the founders of public international law, Las Casas, on his definitive return from the colonies to Spain and until he died, strove to obtain from Charles V and Philip II a law of nations that would promote and guarantee the freedom of peoples and of individuals in the world community.

In the view of present-day publicists and other writers on international affairs, Las Casas is the man who had the merit, shared with the Salamanca theologians, of opposing to the arguments of the legists, and in particular of their common adversary Sepúlveda, the perfect compatibility between the sovereignty of the world empire and the recognition, under its indispensable protection, of the autonomy of native "Indian seignorial domains". He appears as the eminent precursor and exponent of the right of peoples to self-determination, which the codification treaties concluded under United Nations auspices in 1966 have set out proudly at the head of a systematic enumeration and definition of international human rights. 
Las Casas, with the Salamanca theologians, was also the exponent of a humanitarian law to protect, in times of armed conflict, wounded or captured combatants, non-combatants (personnel of the medical armed services) and civilians. It is expressed today in the positive law of the Geneva Conventions, revised in 1949 and whose twenty-fifth anniversary in 1974 coincides with the quincentenary of the year of Las Casas' birth.

While throughout the world Latin humanists paid tribute to the man who was-and is still-the example of an international mediator for human rights, Belgium was celebrating the hundredth anniversary of an otherwise forgotten document in the history of the laws of war: the Declaration of Brussels of 27 August 1874, which had served as a preliminary draft for the Regulations drawn up and revised in 1899 and 1907 by the Peace Conferences at the Hague.

The factor common to those three dates, 1474, 1874 and 1974, may constitute a starting-point for our considerations, within our own disciplines of research and instruction, on the origins and evolution, in the international relations of different human societies, of a law of war which has been formulated and developed from two angles: on the one hand the right to war-i.e. the right to wage war and, on the other hand, the laws of war, which, once hostilities have broken out, lay down rules for the conduct of operations.

This law of war, first laid down around $1474,{ }^{1}$ the year of Las Casas' birth-though the exact date has not been scientifically established-was the subject of a laborious attempt at reaffirmation by a diplomatic conference in 1974. For the first time, representatives of liberation movements were admitted for discussions with the representatives of one hundred and twenty-six States, the High Contracting Parties to the Geneva Conventions of 12 August, 1949.

The law of war, born at the time when the New World was being colonized, is being re-examined today during the final phase of the decolonization of the Third World. In the meantime, in 1874, it was closely linked, in the first attempt to codify it, to the demand by " powers of limited interests » that the great military powers should accept that the law of war be extended to units set up to make up for the lack of permanent armies.

\footnotetext{
${ }^{1}$ By the Spanish theologians, founders of the school of the law of nations.
} 
At each of these stages, it was put forward that the doctrine had a particular role and a special mission to fulfil: to help humanitarian law -the natural law of respect and protection of the human person-to find expression and effective application in the positive law of armed conflicts.

In each of the three examples under consideration, humanitarian law appears to be an objective which positive law finds difficult to achieve and define. The elusiveness of humanitarian law is due to the penetration into the laws of war of the right to war which, at the level of the individual, comes within the purview of international human rights. The two systems must be separated; bringing them together is liable to cause obstruction and even destruction.

\section{1474-1566 - Affirmation and application}

The claim of Las Casas, based on the doctrine of the padres, presented the two elements of a law of war mentioned above in an original perspective of application:

1. The liberation of the Indian peoples and the restitution of their property came under international human rights; these included the right to war which had to be drawn up and accepted on both the Indian and Spanish sides.

2. The barbarous cruelties witnessed by Las Casas as a "clerigo" and colonist, were the deciding factor which led him to protest and to state his policy of a humanitarian law to the central authority, whose support he gained, and to the local colonial authorities, with whom he had to negotiate.

Its formulation was fully grounded on the dialectic of the Gospels, source of the "golden rules" of the laws of war (jus in bello).

The laws of war advocated by Las Casas and his brethren, the padres of America, were favourably received by the Catholic monarchs. Their essential elements were to be found in the "leyes nuevas", inspired by natural law as applied to the law of nations, in accordance with Vitoria's definition (quod naturalis ratio inter omnes gentes instituit vocatur jus gentium).

Las Casas' special merit lay more particularly in his efforts to obtain the effective application of the established norms. The threats uttered by the chaplain of the conquerors, his fierce expostulations were supplemented by a policy of negotiated agreements, which foreshadowed the safety 
zones and non-defended localities of the 1949 Geneva Conventions and of the additional protocols which have been under discussion in 1974, 1975 and 1976. Those authors who have made a special study of Las Casas' work have appropriately pointed to the contract, concluded on 2 May 1537 between Las Casas and Maldonado, which forbade Spaniards for a period of five years to enter territory where a mission was being undertaken. This agreement was secret. ${ }^{1}$ Its aim, to protect and safeguard, was in line with the ultimate goal, which was to substitute conquest by the Gospels for conquest by war.

\section{1874 - Stalemate}

From 27 July to 27 August 1874, a diplomatic conference was held at Brussels, on the initiative and at the invitation of the Tzar of Russia. It sought to introduce, in the positive law of international armed conflicts, some rules of the laws of war on land going beyond the scope of the humanitarian law elaborated in Geneva in 1864, which, although threatened, remained fortunately outside the discussions. ${ }^{2}$

The development of the laws of war, the subject of political negotiations just after the Franco-Prussian war, was eclipsed by a discussion of the greatest importance concerning the scope of the law of war (jus ad bellum). The central question discussed at the conference, which was dominated by the German delegation, was whether an enemy population could be allowed to take up arms. A compromise was worked out, based on the distinction between invasion and occupation.

The written rules which were proposed regarding the conduct of hostilities ( jus in bello), were discredited by this great controversy and were not adopted. The Declaration of Brussels, which remained incomplete and was not accepted, constituted the basis for discussion at the Hague Conference of 1899 , which adopted the famous Regulations respecting the Laws and Customs of War on Land. ${ }^{3}$

1 The full text is reproduced in Saint-Lu, La Vera Paz, esprit évangélique et colonisation, p. 16 et seq.

${ }^{2}$ On the proceedings and consequences of the Brussels Conference, see T. de Breucker, La déclaration de Bruxelles de 1874 concernant les lois et coutumes de la guerre, in Chronique de Politique étrangère, vol. XXVII, No. 1; Danièle Bujard, the Geneva Convention of 1864 and the Brussels Conference of 1874, International Review of the Red Cross, No. 163, Oct. 1974 and No. 164, Nov. 1974; A. Bouekassa, Un centenaire, la Conférence de Bruxelles de 1874 sur les lois de la guerre, an unpublished paper presented at the Institut d'études politiques d'Aix in 1974.

${ }^{3}$ See the articles by Albert de La Pradelle, in Revue générale de droit international public, 1899 , tome VI. 


\section{1974 - Reaffirmation and crisis}

Humanitarian law, which is in the process of "reaffirmation and development" (to supplement the four Geneva Conventions of 1949), is once again faced with a claim for the right to war, extrapolated from the framework of international wars into that of wars of national liberation.

The right of resistance fighters in occupied territory to wage war against the great powers with standing armies-a right demanded in the name of patriotism by the small States at Brussels in 1874-was embodied in the 1949 Geneva Convention after considerable difficulty and discussion.

In 1974, at the Diplomatic Conference in Geneva, this demand regarding the right to war was made anew in favour of "freedom fighters" struggling for decolonization. This development was bound to cause new and extensive discussions.

\section{Conclusion}

The future of the right to war and also of the laws of war, periodically challenged, is dependent on a natural law transcending political claims, which are unceasingly multiplied and wild, and which ignore the individual obligations that are a necessary counterpart to the rights demanded. It is not enough to acclaim and proclaim human rights to justify granting them without thought of requital. International law and order is here the necessary yardstick with which the claims for rights and the boundaries for such demands may be measured.

It is for the international relations experts in all countries to examine, in the common cause of peace, communications and development and, following the example of Las Casas, what influence and action humanitarian institutions might still have in spite of a regrettable politization of human rights in a changing world in which the sovereign powers multiply and swell, as they come into a dangerous contact with the widespread powers which attack them, compete with them and bring about their downfall.

Paul DE GEOUFFRE DE LA PRADELLE

Vice-President of the Institute of International Law, delegate to the 1949

Diplomatic Conference in Geneva 